\section{Reorienting Japanese Studies with Views from the Nan'yō}

\author{
MARIA CYNTHIA B. BARRIGA \\ Waseda University
}

\section{ABSTRACT}

This paper describes how Japanese studies can expand its relevance, approached from my perspective as a Philippine postcolonial historian. In the course of my research on the Japanese locals of Davao and Guam, Japanese studies has been essential. Japanese imperial history has provided me with a regional perspective that transcends the limits of Philippine national historiography and has given me access to source materials about the localities under study. As I became invested in Japanese studies, I realised that Philippine historiography has much to contribute back. A Philippine perspective can question the limits of the concept of who is Japanese, particularly in the case of Filipino-Japanese and CHamoru-Japanese mestizos. Moreover, Japanese historiography, which is still in many cases limited to the archives, may source alternative approaches or methodologies from its Philippine postcolonial counterpart, which has for decades been experimenting with methods of writing more inclusive national histories. More broadly, by conversing with specialists of areas with which Japan has been historically connected, I suggest that Japan scholars can not only extend Japanese studies' relevance beyond its own field but also infuse it with new ideas and approaches.

\section{KEYWORDS}

Asia-Pacific War; Guam; history; Japanese imperial history; Japaneseness; migration; multiethnic identity; multiracial families; nan'yō; Nikkei; Nikkeijin; Philippines; postcolonialism; social and cultural identity; World War II
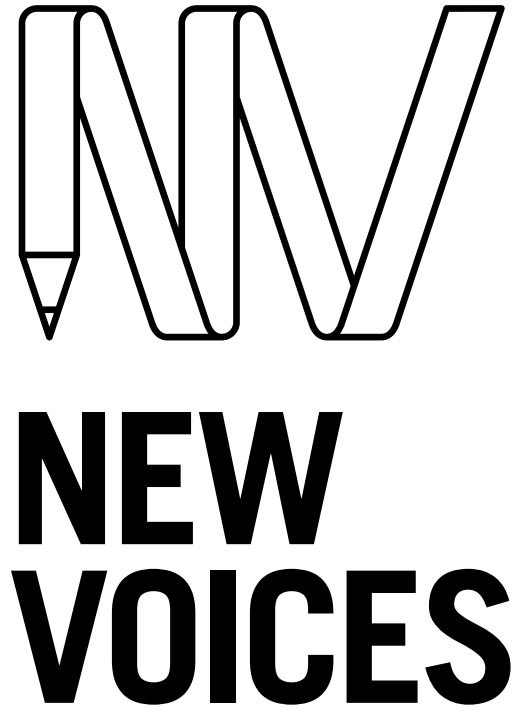

IN JAPANESE STUDIES

JAPANFOUNDATION \& BRINGING JAPAN TO YOU

To link to this article: https://doi.org/10.21159/nvjs.13.d-01

ISSN 2205-3166

New Voices in Japanese Studies is an interdisciplinary, peer-reviewed journal showcasing the work of emerging scholars with ties to Australia or New Zealand and research interests in Japan.

All articles can be downloaded free at newvoices.org.au

(C) The Japan Foundation, Sydney and Maria Cynthia B. Barriga, 2021. 


\section{INTRODUCTION}

Tapanese studies can be relevant beyond its own field. However, in order for this to happen, Japan scholars need to converse more with other area studies specialists working in and on the Asia-Pacific region. As a Philippine historian researching the Japanese locals of Davao (a Philippine province) and of Guam (an island in the Marianas), I propose in this paper a means of expanding Japanese studies through such conversations. ${ }^{1}$ A Philippine and CHamoru postcolonial perspective in Japanese history can reconfigure not only the concepts of 'Japan', 'Japanese' and 'Japanese studies', but also those of 'Filipino' and 'CHamoru'.2 Japanese studies (and area studies in general) are not nationally bound fields that can be studied in isolation. Rather, Japan is part of a global network of constantly moving people, correspondence, goods, ideas, policies, armed forces and so forth (see Appendix). ${ }^{3}$ Seen in this light, Japan scholars have much to offer to and learn from specialists of areas with which Japan has been historically connected.

To show this potential, I first introduce my research and my discipline. Next, I share how Japanese studies-especially its concept of nan'yō (南洋; lit., 'south seas') - and Japanese-language source materials on Davao and Guam have been useful to my research. Then, I point out how my research and my postcolonial approach is useful for Japanese studies specialists, particularly those researching the history of the Philippines and Guam. Nations emerged historically in contexts influenced by continual movements across borders, and therefore do not exist in a vacuum. A global approach to writing history recognises this by allowing a nuanced view of the past and making space for its complexities. My reflections as a Philippine historian show that considering Japanese studies can assist in a global approach to studying both Japan and the Philippines. I conclude the paper by suggesting a view of Japan as part of a larger network and of Japanese studies as an evolving body of scholarship that is in conversation with other area studies specialists.

\section{THE JAPANESE LOCALS OF DAVAO AND OF GUAM}

My research focuses on the Japanese locals of Davao and of Guam during the rapid imperial successions of the 1940s (see Barriga 2020). Both located

1 In this paper I use 'Japanese locals' to refer to people of Japanese ancestry, including settlers and their children, living in Davao and Guam.

2 CHamoru are the indigenous people of Guam. This paper follows the orthography set by Kumisión i Fino' CHamoru yan i Fina'någuen i Historia yan i Lina'la' i Taotao Tåno' (Commission on CHamoru Language and the Teaching of the History and Culture of the Indigenous People of Guam). In this orthography, $\mathrm{CH}$ is considered a single letter and thus is capitalised together as the first letter of a proper noun (Kumisión 2020). Compared with the alternative spelling of 'Chamorro,' 'CHamoru' is closer to the pre-Hispanic language spoken on the island and has been associated with a more assertive stance towards CHamoru self-determination (Taitano n.d.). With the intensification of this movement in recent years, the use of 'CHamoru' instead of 'Chamorro' has been increasing, and was especially apparent in the 2021 Marianas History Conference. 3 Japan's historic interconnectedness with a global network that extended beyond 'the Japanese empire'including states and territories such as Taiwan, Ogasawara, Korea, Manchukuo (present-day Manchuria) and the Nan'yō Guntō (南洋群島; South Sea Islands) — can be seen in the works of Mariko Iijima (2018) on Japanese coffee producers in Taiwan, Hawaii and Saipan. This interconnectedness can also be seen in Eiichiro Azuma's (2019) work on Japanese colonial settlers who moved from the US to other parts of the Americas and East Asia. In a more reflective vein, Japan scholar Sheldon Garon writes of how "serendipitous discoveries in the archives" have shaped his own research experience and can support a global approach to history (2020, 252). The Appendix to this paper features a map illustrating a selection of shipping routes that passed through the AsiaPacific region, thereby providing a snapshot of this interconnectedness.
DISCUSSION PAPER 
in the western end of the Pacific Ocean, the Philippines and Guam were insular territories of the United States during the first half of the 20th century, and at the same time were part of the nan'yo - the area into which imperial Japan would soon expand. Japanese settlers began arriving in Davao in the early 1900s. In the 1910s, Japanese businesses expanded, sparking a problem whereby Japanese enterprises were accused of illicit land acquisition, and the Filipino elites of aiding them. By the 1930s, Davao was economically dominated by Japanese businesses, and varying levels of competition and partnerships emerged between Filipinos and Japanese labourers, landowners, entrepreneurs, public officials and professionals. The Japanese figured prominently in the island society of Guam at the time too, though not reaching the same level of economic dominance and controversy as those in Davao. More importantly, by the 1940 census, most Japanese of Guam were of mixed Japanese-CHamoru parentage. These details raise many questions. How did these Japanese locals experience the Asia-Pacific War and its aftermath? How did their relationships with their fellow Filipino and CHamoru locals change when Japan invaded Davao and Guam in 1941, occupied it under strict military rule, and then lost it to the returning US forces in 1944-45? How did their sense of belonging in the locality shift during the rapid imperial transitions of the 1940s? I have sought to answer these questions in my research to date. ${ }^{4}$

As a Philippine historian, I approach my research from a postcolonial perspective. Since the $16^{\text {th }}$ century, the Philippines had (nominally) been governed under the successive empires of Spain, the US and Japan, and much of its archival materials were written by and for the colonisers. ${ }^{5}$ To counter colonial history, Philippine historians have been pouring their efforts into writing a national history that is meaningful to Filipinos, and not just to the foreigners who happen to be in-or passing by-the islands. This has resulted in a national history that is anchored in anti-colonial movements such as the Philippine Revolution against Spain, the Philippine-American War and the anti-Japanese Filipino guerrilla resistance.

Such an Us-versus-Enemy grand narrative poses major problems to the development of the national historiography. Specifically in the context of the Asia-Pacific War, the Filipinos who collaborated with the Japanese military have been long condemned for betraying Pilipinas, our Mother Nation. Sympathetic historians argue that the Filipino leaders who collaborated with Japan did so to cushion the Filipino people from graver tragedies and to fashion a nation independent of foreign incursion (e.g., Jose 1999, 1998; Yellen 2019). Others show that Filipino volunteer armies allied themselves with Japan with the hopes of liberating the Philippines from the US (e.g., Terami-Wada 1999; Quibuyen 2011). But what of the Filipino-Japanese mestizos (mixed-race people) who held “'dual (or even more multiple) sentiment' [sic] of belonging” (Yoneno-Reyes 2011, 236)? What of the hybrid Davao settler zone?

\footnotetext{
4 The complexity of social relations at the local level is evident in oral histories both by Filipinos in Davao (e.g., Vallejo 2009) and Japanese repatriates in Japan (e.g., Maruyama 2008), and in primary sources such as those written by the Davao Japanese Association chapter presidents to the Japanese military immediately after its invasion of Davao in 1941 (Mori 1993). Besides the author's aforementioned dissertation (2020), see also Barriga (2015).

5 Although the empires imagined the entire Philippine archipelago as their territory, Spain did not govern most of Mindanao Island, the Mountain Province and many other localities. Likewise, throughout the Japanese Occupation (including the Independent Philippine Republic under Japan), pockets of areas controlled by Filipino anti-Japanese guerrillas proliferated.
} 
To write a history of Davao in the tumultuous 1940s, I necessarily had to liberate myself not only from empire-focused colonial history, but also from its monolithic counter-narrative of Filipino nationalist history. My brand of postcolonial historiography, thus, zooms in on Davao, taking into consideration the various ethnic, national and regional sentiments of belonging that converged within it. The Japanese and the Filipinos in my work may be nationals of Japan and of the Philippines, but they are first and foremost locals of Davao.

\section{EXPANDING PHILIPPINE HISTORIOGRAPHY THROUGH JAPANESE STUDIES}

The Philippine historiography of the Asia-Pacific War holds up 'the Japanese' as the enemy which invaded the nation and against which the Filipinos prevailed. To study the Japanese locals of Davao in a manner that neither condemns nor defends 'the Japanese', I searched for a non-Philippine locality with which to compare Davao. The logical choice was Guam, the only other place that shares the same historical experience of being colonised by Spain, the US, Japan and the US again. ${ }^{6}$ However, as I ventured in my research towards Guam, concerned friends warned that if I continued, I would lose funding, publication and employment opportunities. Guam, they warned, is in Oceania, well outside of Asia and Asian studies.

What allowed me to overcome this barrier was the concept of nan'yo, a term used by the Japanese empire from the late 19th century to encompass the region that spanned Southeast Asia and Micronesia. ${ }^{7}$ Combining a nan'yō perspective of the region with the US imperial history that is well-established in the Philippines, I came to view Davao as being 'between two empires': it was connected to the US and Japan as well as to the Philippines (see Appendix). ${ }^{8}$ Likewise, Guam was linked not only to the Marianas but also to Manila, continental US and (indirectly via Manila or Saipan) Japan. In this view,

6 The Philippines declared independence from the US in 1946, while Guam remains as a US territory today. Understandably, much has been written about Guam's political status as an 'unincorporated territory' of the United States, and its decolonisation and CHamoru self-determination movements. As I detail in "Towards an Interconnected Pacific" (2018), these themes are tackled not only by Guam scholars, but also by their counterparts in Japan. Meanwhile, the legacy of US colonialism remains in the Philippines (e.g., McFerson 2002). Interestingly, while there have been studies that find parallels between the Philippines and Japan (e.g., Fujiwara and Nagano 2011) and Guam and Japan (e.g., Matsushima 2016) as places under the US sphere of influence, very rarely are the Philippines and Guam discussed together. One rare example is Shigematsu and Camacho's Militarized Currents (2010), a collection of essays foregrounding the connections forged by the US and Japanese imperialism in the Asia-Pacific.

7 In his seminal work, Nan'yo, Mark Peattie (1988) traces the Japanese imperial history in the region from 1885 to 1945. After World War I, the League of Nations mandated the administration of the former German-occupied Micronesia to Japan. Calling the area 'Nan'yō Guntō' (南洋群島; South Sea Islands), Japan established the Nan'yō-chō (南洋庁; South Seas Bureau) for this purpose in 1922. As historian Wakako Higuchi (1987) explains, Japanese officials distinguished between 'inner nan'yō', which pertained to the Nan'yō Guntō, and 'outer nan'yō', which pertained to the region beyond (29 n5). Pacific studies scholar Yumiko Imaizumi (2014) notes that, for Japan, the Nan'yō Guntō was a base from which to economically expand to the outer nan'yō (276-77). In her explanation, 'outer nan'yö' referred to places in Southeast Asia where Japanese communities flourished economically. In this definition, Davao was part of the outer nan'yō. Meanwhile, Guam occupied an outlier position, belonging neither to the Nan'yō Guntō (because it was under US administration) nor to the outer nan'yō (because of its geographical location).

8 Eiichiro Azuma's Between Two Empires (2005), which showed the transnationalism of Japanese immigrants in the US during the decades leading to World War II, was instrumental in forming my framework. However, as Kiichi Fujiwara and Yoshiko Nagano's (2011) edited anthology The Philippines and Japan in America's Shadow recently reminded me, the idea that the Philippines was in between the US and the Japanese empires was advanced long before by Theodore Friend (1969) in his Between Two Empires: The Ordeal of the Philippines, 1929-1945 (cited in Fujiwara and Nagano 2011). 
Davao, Guam, Japan and the US were all associated by various flows of people, ideas, money and goods crisscrossing the Asia-Pacific. In brief, the imperial history of Japan (and the US) provides a regional perspective that allows me to transcend the limits of both Philippine historiography and Asian studies.

In addition to this regional perspective, knowledge of the Japanese language and access to Japanese resources are essential for my research. Many primary sources related to Philippine history are written in the Japanese language and housed in libraries and archives in Japan. It was to access these that I began learning the language and acquainted myself with the National Diet Library, Cinii (a Japanese database of journal articles and books) and the digital repositories of universities in Japan. Once I had access to the source materials, I soon learned that fellow Philippine and Guam historians appreciate the information I can offer, as very few of them can access Japanese collections and read materials in the Japanese language. For example, in 2018, I wrote an English-language paper which reviewed and contextualised Japanese works about Guam written from the 1920s to the present. ${ }^{9}$ This historiographical paper appears in Pacific Asia Inquiry, a journal published by the University of Guam. Despite the limitations of the paper, the editor of the issue acknowledged:

"In my opinion, this article is necessary reading for anybody interested in how Guam has been viewed by Japanese authors, editors and readers over time. Particularly noteworthy is its analysis of the manner in which Japanese perspectives have changed in recent decades to a much more sympathetic concern with the social and cultural needs of the island."

(Gugin 2018, 7)

To understand our neighbours, to know how to respond to them, and to place ourselves within the history of the Asia-Pacific region, Filipinos and CHamoru find value in the knowledge of the Japanese language and in Japanese source materials.

\section{APPROACHING JAPANESE STUDIES FROM A PHILIPPINE PERSPECTIVE}

Philippine and Guam historians likewise have much to offer Japanese scholarship. Among the works on the history of the Japanese in Davao, there are common assertions which a Philippine perspective can reassess and nuance. The plethora of histories on the Japanese in Davao are undergirded by the presupposition that people of Japanese ancestry-be they issei, nisei, sansei or, generally, Nikkeijin - are Japanese or want to be recognised as Japanese (e.g., Hayase 2014; Ohno 2015). ${ }^{10}$ In his chapter on the Japanese residents of Davao during the Japanese military occupation of the Philippines, historian Shinzo Hayase (2014) asserted that Okinawans and Filipino-Japanese individuals, having been discriminated against in Japanese society, served Japan with much enthusiasm to prove themselves at par with the Japanese from the mainland (174). Similarly, Shun Ohno (2015) asserted that the Nikkeijin who 
remained in post-war Philippines hid their Japanese identity in fear of Filipino anti-Japanese sentiment, reclaiming it decades later with the help of Japanese activists who lobbied for their recognition by the Japanese government. But, why would these Filipino-Japanese have served Japan in the ardent desire to prove themselves Japanese when they were born and raised in the Philippines by Filipino mothers and most likely had never seen Japan? If the Nikkeijin who remained in the Philippines were so persecuted by Filipinos after the war, how did they survive? If they survived by the aid of pro-Japanese indigenous Filipino communities, then why did they have to hide their Japaneseness? Or, did they hide it only from certain people in certain contexts?

Following Taku Suzuki's (2010) observation in his work with Japanese Bolivians, I highlight "the fluid and situational senses of belonging they experienced in the places they lived and worked" (183). In my study, I found that, in contrast to Ohno's contention in his Transforming Nikkeijin Identity (2015), Nikkeijin identity did not oscillate in a dualistic way between the absolutes of being Japanese and being not Japanese. Being Filipino and being Filipino-Japanese must also be considered. Here, identities are consistently shifting, contended and relational. To my question of what befell the Japanese of Davao during the successive imperial transitions surrounding the AsiaPacific War, I found that their identity and sense of belonging shifted between being Japanese, Filipino and mestizo. During the most violent months of 1944 and 1945, these shifts were characterised by conflicted loyalties and senses of belonging. Ohno's intergenerational study of the Philippine Nikkeijin spanned a century's worth of history and remains an important work; however, the reality is more nuanced than his analysis allows. From this example, it is evident that a Philippine perspective-or more broadly, a view from the $n a n ' y \bar{o}$ - can expand Japanese studies' approach to studying 'Japanese identity'.

Besides prompting us to reassess common assertions, Philippine (and CHamoru) postcolonial historiographies can also enrich how historical methods are approached in Japan. As mentioned, many primary sources on Davao are written in the Japanese literature. Even in English-language sources, written by Americans and Filipinos from outside Davao, Japanese pioneers are most often hailed as the developers of the Davao frontier. As YuJose and Dacudao (2015) have shown in their article in Philippine Studies, the narrative of Davao's development has become one wherein the Japanese are visible, while Filipinos are invisible-an invisibility not uncommon in colonial histories globally. If such is the state of the archives, then Philippine historians (like historians of other colonised or decolonising places globally) must search for alternative methods of writing history.

Spurred by the need to augment not only colonial history but also Manilacentric national history, Philippine historians have for many years experimented with methodologies. In the 1950s, when public school teachers nationwide collated local histories, most employed oral interviews due to the lack of historical documents. ${ }^{11}$ In the 1970s, to support his critique of Philippine historiography, Alfred McCoy (1977) conducted interviews alongside analysis of documents. Around this time, William Henry Scott

11 Housed in the Philippine National Library, this collection is officially called "Historical Data (Philippines)" and popularly referred to by Philippine historians as "Historical Data Papers." 
(1978), a Philippine historian focussing on the $16^{\text {th }}$ century, proposed to purposefully search for Filipino agency within colonial documents by reading archival materials against the grain. Meanwhile, Reynaldo Ileto (1979), another Philippinist, used the pasyon to write a "History from Below" (ch. 1), telling the history of the masses and not only the literate elites. ${ }^{12}$ In short, it is a foregone conclusion in the Philippines that writing history requires more than verifying, cataloguing and stringing together data from historical documents.

Postcolonial perspectives and methodologies such as these should prove useful to Japanese historians, many of whom are still very much reliant on the archives (Bowie 2018, 860), just as they have proven useful to me in my own work. Recognising the scarcity of Philippine voices in the archives, I realised that in order to understand the complexity of Davao's Japanese locals and move beyond an image of them as "second-class citizens [of Japan]" (Hayase 2014, 174) residing in "Dabao-kuo" (149), then I too needed to employ alternative historiographical methods from the former nan'yo.$^{13}$ For example, in my research I refer to the Dabao Shimbun, the wartime Japanese newspaper of Davao, for insights into Davao society and events of the time. Shinzo Hayase has pointed out that Dabao Shimbun was a branch of Manila Shimbun, in turn "managed by the Tokyo Nichi-Nichi Shimbun and Osaka Mainichi Shimbun publishing companies" $(2014,153)$. Hayase finds that the newspaper "concentrated on information about Japan and the world...all for the purpose of helping local Japanese residents keep in touch with their homeland" (154). Although I am familiar with this background and general trend, when using this source I choose to focus on the aspects related to Davao, regardless of how small the space they occupy in the broadsheet-for example, the ads by local businesses, movies screening at the local theatres, and notices about missing children. Hayase published numerous useful research tools and catalogues, and his 1984 dissertation remains a classic even for Philippine historians studying Davao. I defer to the breadth of this knowledge of archival materials; it has provided me with a solid foundation for my methodological experimentations. However, I am also careful not to dismiss the details of local life in Davao that this source can illuminate. To write a history that does not perpetuate a hegemony of the literate and the elite, nor of the colonial archives and the structures that created and sustain them, postcolonial methodologies-so-called 'reading against the grain' and using alternative sources-were essential to my research on the Japanese in Davao and Guam. Historians of Japan, especially those studying minorities and migrants, might also find these methodologies useful.

\section{CONCLUSION}

In my pursuit to expand Philippine historiography, my ability to draw upon Japanese studies has been essential. Besides broadening my pool of source materials to include Japanese-language texts, the geographic expanse of the Japanese empire's nan'yō has also broadened my perspective beyond the

12 The pasyon is a Philippine epic that is traditionally chanted during Lent.

13 In 1930s, Davao was often called Dabao-kuo (ダバオ国) by both Japanese and Filipinos, after the Japaneseoccupied state of Manchu-kuo (present-day Manchuria). It was a testament to the Japanese economic influence on the Philippine frontier. 
confines of Philippine national history, allowing me to better position the Japanese locals of Davao within the region and to incorporate Guam as an analogous region. The more I read and talk to historians of Japan, the more I realise that Philippine historical studies too can contribute to Japanese imperial history. A Philippine perspective augments Japanese historians' approaches to studying Japanese people in the Philippines, especially considering those of Filipino-Japanese parentage. Moreover, Philippine postcolonial methodologies enable the writing of inclusive histories that extend beyond the literate elite.

While Japanese studies has significant potential for relevance to other area studies specialists, for this to be realised its scholars must continually reorient their views and methodologies as they converse with colleagues working in and on other regions-in this case, the former nan'yō. Seeing Japan as part of a web that spans the globe and its people as part of this web's "flows" and "vortices" (Pendleton 2020) will require its scholars to put at bay their ideas of 'Japan' and how history should be written. Nevertheless, such global perspectives enrich Japanese studies and continue to extend its significance beyond its current bounds.

\section{APPENDIX: 'JAPAN AS PART OF A GLOBAL NETWORK'-MAP, OVERVIEW AND SOURCES}

\section{Map 1: Japan as Part of a Global Network: Focus on Davao and Guam}

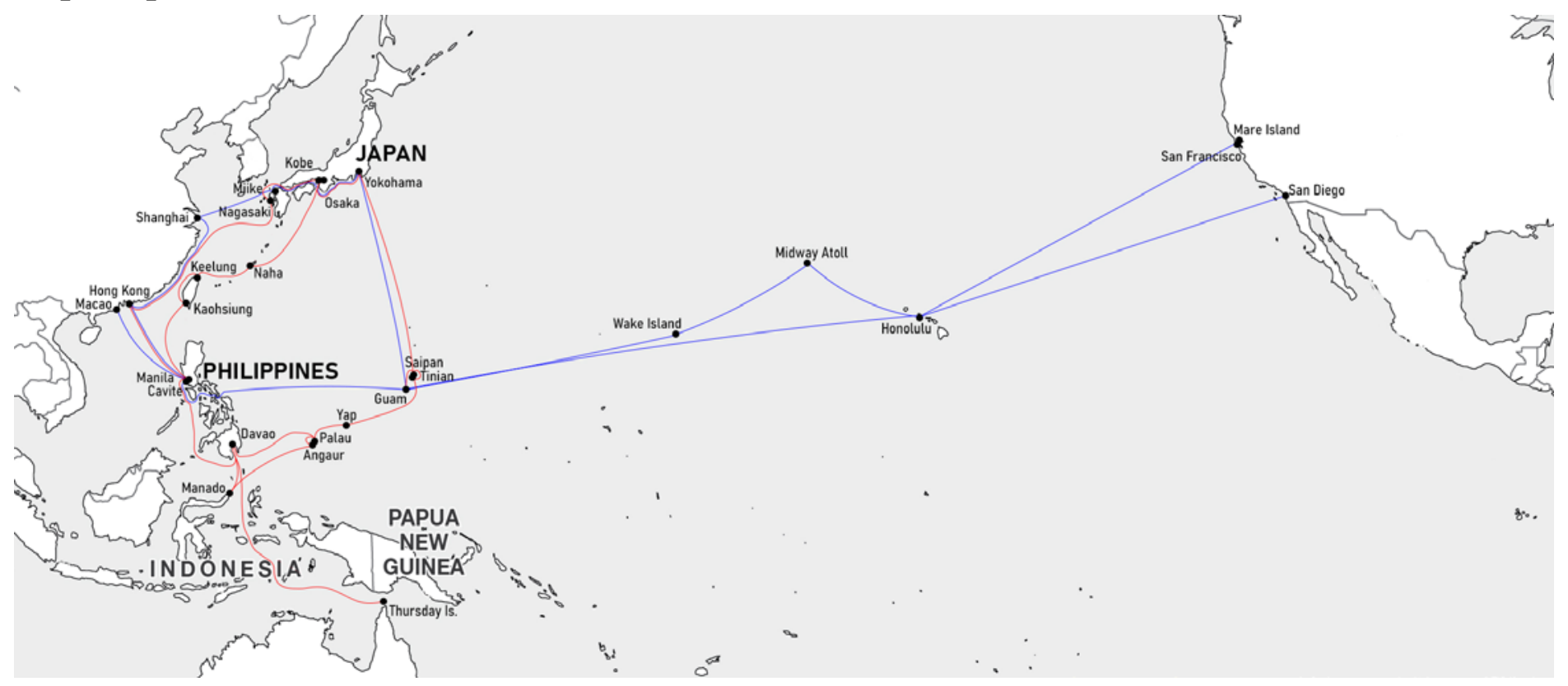

Base map: 'Countries Bordering on the Pacific Ocean', reproduced with the permission of CartoGIS Services, Scholarly Information Services, The Australian National University (CC-BY-SA 4.0). Route lines by the author and New Voices in Japanese Studies.

This map illustrates a sample of major commercial and military shipping routes from 1929 to 1940 that docked at the author's case study locations, Davao and Guam. The routes represented in the map include those operated by the US Navy and Pan American Airways that called at Guam, plus the Japanese-operated routes of the Mariana Maru (the only Japanese vessel that was allowed to dock at Guam), and two commercial Japanese shipping companies that passed through Davao. The map is by no means comprehensive; 
in particular, the Filipino and American lines that stopped at Davao's Santa Ana Wharf and Sasa Airport are not reflected. However, the purpose of the map is not to provide a complete catalogue of routes, but rather to contextualise my argument with a snapshot of the interconnectivity in the region in the lead-up to the Asia-Pacific War.

The routes represented in the map are drawn from the archival sources listed below. As can be seen, most of the sources include only the stops. The route lines are supplied by the author and the editor and are intended as a guide only. Lastly, for consistency, this appendix and the map foreground presentday and internationally recognised place names. Where alternative names are used in the primary sources cited, these are supplied in square brackets below.

\section{Japanese-Operated Vessels (Red Route Lines)}

\section{Mariana Maru}

Mariana Maru was the only Japanese vessel that called at Guam's Apra Harbor. It was owned by a Japanese local of Guam, a merchant named Jose Shimizu. According the historian Wakako Higuchi (1998), Mariana Maru last sailed in 1939 (159).

- Yokohama, Saipan, Guam (Guam Recorder, March 1929, "Shipping Notes")

\section{Nippon Yūsen Kaisha (日本郵船会社)}

Nippon Yūsen Kaisha was one of the primary shipping companies that included Davao in its routes.

- Ura-nanyō (裏南洋) Outbound Route: Kobe, Yokohama, Saipan, Tinian, Yap, Palau, Angaur, Manado [Menado], Davao (Nippi Shinbun, 1 October 1935, p.9)

- Ura-nanyō Return Route: Davao, Palau, Yap, Saipan, Tinian, Yokohama, Osaka, Kobe (Nippi Shinbun, 1 October 1935, p.9)

- Australia Outbound Route: Yokohama, Kobe, Nagasaki, Hong Kong, Manila, Davao (Nippi Shinbun, 1 October 1935, p.9). After stopping at Davao, the line proceeded to Thursday Island (Kamohara 1938)

- Australia Return Route: Davao, Manila, Hong Kong, Nagasaki, Kobe, Yokohama (Nippi Shinbun, 1 October 1935, p.9)

\section{Osaka Shōsen Kaisha (大阪商船会社)}

Osaka Shōsen Kaisha was another shipping company that appears in archival materials from the time, although not as frequently as Nippon Yūsen Kaisha. It also operated a route that stopped at Davao.

- Kaohsiung [Takao], Keelung, Naha, Kobe, Yokohama (e.g., Davao Times Weekly, 22 August 1940, p. 5). Although OSK's ads in Davao Times Weekly do not include Davao and Manila, I have included both ports based on the map in Kamohara (1938).

\section{DISCUSSION PAPER}




\section{US-Operated Vessels (Blue Route Lines)}

\section{US Navy}

Several US Navy vessels that called at Guam followed similar routes.

- Manila or Cavite, Guam, Honolulu, San Francisco or Mare Island or San Diego (Guam Recorder, February 1929, "Shipping Notes”; Guam Recorder, Feb 1929, "Shipping Notes")

- Yokohama, Guam, Manila (Guam Recorder, May 1935, "Shipping Notes")

- Guam, Yokohama, Miike (in Fukuoka), Shanghai, Hong Kong, Manila, Guam (Guam Recorder, October 1938)

\section{Pan American Airways}

In the 1930s, Pan American Airways maintained a fleet of clippers, which carried passengers and cargo. Dubbed "flying boats," they traversed the Pacific Ocean, with routes stopping in Guam.

- San Francisco, Honolulu, Midway Atoll, Wake Island, Guam, Manila, Macao (also Macau) or Hong Kong (Pan American Airways [1939])

\section{REFERENCES}

\section{Primary Sources}

Davao Times Weekly. 22 August 1940. National Library of Australia. Bib ID 495600.

Guam Recorder. February 1929 - October 1938. Micronesian Area Research Center, University of Guam. Call No. DU647.A23 C.1.

Kamohara, H. [蒲原廣二]. 1938. Dabao Hōjin Kaitaku-shi [ダバオ邦人開拓史]. Davao: Nippi Shimbun-sha [日比新聞社].

Mori, H. [森 治樹]. 1993. “Taiheiyō sensō to Dabao zairyū hōjin” [太平洋戦争とダバ 才在留邦人]. In Senka ni kieta Dabao kaitaku imin to Manira asa: Dabao kaitaku imin jitsuroku-shi [戦禍に消えたダバオ開拓移民とマニラ麻一ダバオ開 拓移民実録史], by Dabao-kai [ダバオ会], 243-300. Fussa [福生]: Dabao-kai [ダバオ会].

Nippi Shimbun [日比新聞]. 1 October 1935. National Library of Australia. https://nla. gov.au:443/tarkine/nla.obj-369638815.

Pan American World Airways. [1939]. "Pan American World Airways route map from 1939 timetable," Cleared to Land: The Records of the Pan American World Airways, Inc. Accessed 13 July, 2021. https://scholar.library.miami.e $\mathrm{du} /$ digital/exhibits/show/panamerican/item/680.

\section{Secondary Sources}

Azuma, E. 2005. Between Two Empires: Race, History, and Transnationalism in Japanese America. Oxford: Oxford University Press. 
2019. In Search of Our Frontier: Japanese America and Settler Colonialism in the Construction of Japan's Borderless Empire. California: University of California Press.

Barriga, M. C. 2015. "The Asia-Pacific War in the Davao Settler Zone, December 1941." Kasarinlan: Philippine Journal of Third World Studies 30 (1): 56-90.

2018. "Toward an Interconnected Pacific: An Historiography of Guam in Japan." Pacific Asia Inquiry 9 (1): 21-35.

2020. “The 'Japanese' Locals of Davao and of Guam: Shifting Belongings amidst Successive Empires during and after the Pacific War." $\mathrm{PhD}$ dissertation, Waseda University.

Bowie, K. A. 2018. "Palimpsests of the Past: Oral History and the Art of Pointillism." Journal of Asian Studies 77 (4): 855-77. https://doi.org/10.1017/S002191 $181800092 \mathrm{X}$.

CartoGIS Services, College of Asia and the Pacific. 2020. "Countries Bordering Pacific Ocean.” Australian National University. Accessed 12 July 2021. http://asiapacific.anu.edu.au/mapsonline/base-maps/countries-borderingpacific-ocean

Fujiwara, K. and Y. Nagano. 2011. The Philippines and Japan in America's Shadow. Singapore: NUS Press.

Garon, S. 2020. "Writing Transnational History through Archival Sources." In Studying Japan: Handbook of Research Designs, Fieldwork and Methods, edited by N. Kottmann and C. Reiher. 252-25. Baden-Baden: Nomos Verlagsgesellschaft. https://doi.org/10.5771/9783845292878-252.

Gugin, D. 2018. "Editor's Note: The New Pacific." Pacific Asia Inquiry 9 (1): 7-8.

Hayase, S. 2014. The Japanese in Modern Philippine History. Tokyo: Waseda Institute for Asia-Pacific Studies.

Higuchi, W. 1987. Micronesia under the Japanese Occupation: Interviews with Former South Seas Bureau and Military Officials. Guam: Micronesian Area Research Center.

. 1998. "A History of Pre-war Japanese Residents of Guam." In Guam History: Perspectives Volume 1, edited L. Carter, W. Wuerch and R. R. Carter, 141-80. Guam: Richard Taitano Micronesian Area Research Center, University of Guam.

Iijima, M. 2018. "Coffee Production in the Asia-Pacific Region: The Establishment of a Japanese Diasporic Network in the Early 20th Century." Journal of International Economic Studies 32: 75-88. https://hdl.handle.net/10114/ 13934.

Ileto, R. C. 1979. Pasyon and Revolution: Popular Movements in the Philippines, 1840-1910. Quezon City: Ateneo de Manila University Press. 
Imaizumi, Y. [今泉 裕美子]. 2014. “Taiheiyō no 'chiiki' keisei to nihon: nihon no nan'yō guntō tōchi kara kangaeru” [太平洋の「地域] 形成と日本: 日本の南洋群 島統治加考える]. In Iwanami kōza nihon rekishi dai-20-kan chiiki-ron (teema-kan 1) [岩波講座日本歴史第20巻地域論 〈テーマ巻1〉], edited by $\mathrm{T}$. Ōtsu [大津 透] et al., 263-94. Tokyo: Iwanami Shoten [岩波書店].

Jose, R. 1998. Kasaysayan: The Story of the Filipino People, Volume 7: The Japanese Occupation. [Manila?]: Asia Publishing Company Limited.

. 1999. "The Rice Shortage and Countermeasures during the Occupation." In Philippines under Japan: Occupation Policy and Reaction, edited by S. Ikehata and R. Jose, 197-214. Quezon City: Ateneo de Manila University Press.

Kumisión i Fino' CHamoru yan i Fina’någuen i Historia yan i Lina'la' i Taotao Tåno' (Commission on CHamoru Language and the Teaching of the History and Culture of the Indigenous People of Guam). 2020. "Utugrafihan CHamoru, Guåhan (Guam CHamoru Orthography).” September. Accessed 10 June, 2021. https://kumisionchamoru.guam.gov/sites/default/files/ utugrafihan_chamoru_guahan.pdf.

Maruyama, T. [丸山 忠次]. 2008. Dabao ni kieta chichi [ダバオに消えた父]. Nagoya: Fūbai-sha [風媒社].

Matsushima, Y. [松島 泰勝]. 2016. Review of Amerika to Guamu: Shokuminchishugi, reishizumu, senjūmin [アメリカとグアム: 植民地主義、レイシズム、先住 民] by R. Nagashima [長島 怜央]. Hōsei Daigaku Ōhara Shakai Mondai Kenkyūjo Zasshi [法政大学大原社会問題研究所杂誌] 694: 45-49.

McCoy, A. 1977. Yloilo: Factional Conflict in a Colonial Economy, Iloilo Province, Philippines, 1937-1955. PhD dissertation, Yale University.

McFerson, H. M. 2002. Mixed Blessing: The Impact of the American Colonial Experience on Politics and Society. Westport: Greenwood Press.

Ohno, S. 2015. Transforming Nikkeijin Identity and Citizenship: Untold Stories of Japanese Migrants and Their Descendants in the Philippines, 1903-2013. Quezon City: Ateneo de Manila University Press.

Peattie, M. 1988. Nan'yo: The Rise and Fall of the Japanese in Micronesia, 1885-1945. Honolulu: University of Hawai'i Press.

Pendleton, M. 2020. “Virtual Roundtable: The 'Rebirth' of Japanese Studies," Paula R. Curtis. Accessed 23 May, 2021. http://prcurtis.com/events/AAS2020/MP/.

Quibuyen, F. C. 2011. "Japan and America in the Filipino Nationalist Imagination: From Rizal to Ricarte." In The Philippines and Japan in America's Shadow, edited by K. Fujiwara and Y. Nagano, 106-31. Singapore: NUS Press.

Scott, W. H. 1978. "Cracks in the Parchment Curtain.” Philippine Studies 26 (1/2): $174-91$. 
Shigematsu, S. and C. Camacho. 2010. Militarized Currents: Toward a Decolonized Future in Asia and the Pacific. Minnesota: University of Minnesota Press. https://doi.org/10.5070/T832011607/.

Suzuki, T. 2010. Embodying Belonging: Racializing Okinawan Diaspora in Bolivia and Japan. Honolulu: University of Hawai'i Press. https://doi.org/ $10.1515 / 9780824860547$.

Taitano, G. n.d. "Chamorro vs Chamoru," Guampedia. Last modified 11 October, 2019. Accessed 23 May, 2021. https://www.guampedia.com/chamorro-vschamoru/.

Terami-Wada, M. 1999. “The Filipino Volunteer Armies." In Philippines under Japan: Occupation Policy and Reaction, edited by S. Ikehata and R. Jose, 59-98. Quezon City: Ateneo de Manila University Press.

Vallejo, M. S. 2009. The Battle of Ising: The Untold Story of the 130th Infantry Regiment in the Liberation of Davao and Mindanao, Ising (Carmen), Davao del Norte, Mindanao, May 3-10, 1945. Davao City: Eres Printing Corp.

Yellen, J. 2019. The Greater East Asia Co-Prosperity Sphere: When Total War Met Total Empire. Ithaca: Cornell University Press. https://doi.org/10.7591/ 9781501735554 .

Yoneno-Reyes, M. 2011. "Singing of Modernity and US Shadow: Bodily Aesthetics and Ideology in Salidummay and Shoka." In The Philippines and Japan in America's Shadow, edited by K. Fujiwara and Y. Nagano, 227-58. Singapore: NUS Press.

Yu-Jose, L. and P. Dacudao. 2015. "Visible Japanese and Invisible Filipino: Narratives of the Development of Davao, 1900s to 1930s." Philippine Studies 63 (1): 10129. https://doi.org/10.1353/phs.2015.0002.
DISCUSSION PAPER 